\title{
Conflict between Individual and Society : A Brief Review of Victims and Survivors in Anita Desai's Fiction Dr Pinky
}

PGT in English, Doon International School, Karnal, Haryana, India

\begin{abstract}
Anita Desai's novels catch the shattered psyche of the individuals who are striving for defining themselves in the form of identity in the familial and social set-up but it is hard to say that all the characters are strong enough to survive after dealing with the cruelties of life. Apart from a few, they become the victims of their personal and social affairs of life. It may be observed that almost all the protagonists of Anita Desai are sensitive or hypersensitive that makes them victims. On the other hand, some characters try hard to cope with the abnormalities of life but in the long run they also surrender yet they are able to survive. Through a brief study of the selected novels of Anita Desai, this paper will try to examine who are the victims and who are the survivors?
\end{abstract}

Keywords : Conflict, Society, Victim, Survivor

Anita Desai was writing at a time when Indian society was facing the impact of modernity in urban areas to a great extent. She portrays in her novels the impact of modernity on a traditional society of India and the ramifications of such change on a society and relationships with great sensitivity. She portrays female characters, their response, behavioural attitudes and outlook to changes coming into their lives. Although her protagonists have an intense strive for defining their identity in the familial and social setup but it is hard to say that all the characters are strong enough to survive after confronting with the cruelties of life. Apart from a few, they become the victims of their personal and social affairs of life:

Looking at the sensitive portrayal of characters, it can be concluded that she cares for the individual human beings irrespective of their being male or female. Her characters appear to be exceptionally talented but constantly disturbed by familial ties. As a result, they experience discomfort and feel trapped in an oppressive environment. In most cases the hostile environment frustrates the aspirations of the individual either leading them to their annihilation on a humiliating compromise (George 159).

'Annihilation or humiliating compromise' - it depends on an individual that how long he or she is tortured by the failures and how much he or she is sensitive. But it may be observed that almost all the protagonists of Anita Desai are sensitive or hypersensitive that makes them victims. On the other hand, some characters try hard to cope with the abnormalities of life but in the long run they also surrender yet they are able to survive. Now we will try to examine through a brief study of the novels of Anita Desai that who are the victims and who are the survivors? 
In Cry, the Peacock, a hypersensitive young girl Maya lives a life of horror and fear because she believes in the prophecy of albino astrologer that either she or her husband has to die in the fourth year after her marriage. Now it is four years since Gautama and Maya are married. Maya feels uneasy when Gautama never gives her chance of being close to him because he believes in the theory of attachment preached by the Gita. Maya has no other friend who can pacify her.

As an ideal wife she loves Gautama very much and she always thinks of getting close to him because her own world was "...hell. Torture, guilt, dread, imprisonment-these were the four walls of my private hell, one that no one could survive in long. Death was certain..." (Cry, the Peacock 102). In her alienation she is always aware of the fact that she is gradually going insane. She says, "I am moving further and further from all wisdom, all calm and I shall be seen mad, if I am not that already..." (Cry, the Peacock 108). This shows her neurotic condition. The doctor advises her to free herself from "anxieties and excitements" (Cry, the Peacock 227). But Gautama, instead of being a friendly and cooperative husband, always criticises her by saying "neurotic" to her. He also remarks, "From a passion of wonder and excitement you are led surely to a passion of unhappiness in its loss, depression and disillusionment" (Cry, the Peacock 103).

While criticizing Maya's state of mind, Gautama is not aware of her fears, desires and loneliness. But the prediction of the albino creates a terrible commotion in her consciousness. She turns insane and kills her husband. When she is taken to her father's house, she forgets the death of her husband in the joy of her getting back to her father's house. When her sister-in-law Nila asks her about the incident she describes casually, "So then I pushed him, hard, and he fell. And when I went down the stairs to the terrace he was lying there don't you like your tea?" (Cry, the Peacock 214) Suddenly, Maya's frightened voice is heard from the balcony. It indicates that she also kills herself:

Maya's tragedy is that there is no one to share her feelings. Childless, with an uncaring husband, she is lonely and loneliness is the bane and burden of her psyche. And to cap it all she is not even sexually satisfied (Pandey 83).

Maya becomes the victim of the prediction of the albino, her father's over protectiveness, Gautama's detachment and her hypersensitivity. When she is unable to bear the burden of life, she is victimised by death itself. With her, Gautama also falls in the category of victims because of his extreme sense of non-attachment while living in the system of attachment i.e. family.

In Voices in the City, Nirode's mother and her three children come to Calcutta and are lost in the city of Goddess Kali. Where Monisha lives with her in-laws seems to her a prison. She says, "I am locked apart from all of them, they cannot touch me" (Voices in the City 240). Manisha's marital life is an expansion of Maya-Gautama relationship. Like Maya, she is also frustrated, alienated and childless. Her desires of intimacy and her lack of communication with her husband make her existence insignificant. In her dejection she cries out, "I have not given birth, I have not attended death. All the intervening drama has gone by, unwound itself like a silent blurred film that has neither entertained nor horrified one (Voices in the City 115). Her relation with her husband Jiban is marked by loneliness. Even the other members of the family are not on equal terms with her. The culmination of her married life is when she is alleged of stealing money from her husband's pocket without his knowledge. Instead of establishing the authority of her wife, Jiban supports his mother. The only way to escape from this state of non-existence is to live in solitude: "I find on this level that solitude 
that becomes for me most naturally. I am willing to accept this status then, and to live these, a little beyond and below everyone else, in exile" (Voices in the City 138).

Thus she has to make a choice between death and mean existence and finally she chooses death and commits suicide:

Monisha prefers non-existence to a meaningless existence; she defines love as 'an awake condition of the conscience' but fears and avoids it, because love then implies a sense of duty. Hence she remains in 'an exile' in her two families - mother's as well as husband's. Thus Monisha's hypersensitivity does not help her relate herself meaningfully to the outer reality; she fails to synthesise the ideas of personal freedom, domestic duties and social responsibilities (Rao 170).

Her brother Nirode is another victim of Calcutta being confronted with a long series of failures. Amla also realizes the hollowness of life and the futility of her existence in city in spite of all the "stimulation of new experiences, new occupations, new acquaintances and mild sweet winter air, this sense of hollowness and futility persisted." (Voices in the City 157). We also have the glimpses of marital disharmony between Nirode's parent too. But all remain survivors despite being entirely frustrated except Monisha because she cannot tolerate her tortured life and commits suicide.

The major characters Dev, Adit and Sarah in Bye-Bye Blackbird experience a different type of defeat and disillusionment. Dev arrives in London to join London School of Economics. But soon he feels frustrated and develops hatred for the city and its dwellers because he is horrified by the ill-treatment given to the coloured immigrants. Dev comes across many different incidents of insult that torture him emotionally. He feels insulted and unwanted. But as time passes by, Dev develops a great fascination for the English people and the English countryside. It creates a dilemma for him so that he cannot decide whether to go back to India or, "not to marry and breed, go to office, come home and go to office again but to know a little adventure, to know, to know" (Bye-Bye Blackbird 123). Initially, Adit enjoys his life with his wife Sarah in England. Soon he begins to realize that he has been betraying his self so long. He starts disliking England. Finally, he realises he should face the reality by going back to India where his son would be born.

Sarah feels displaced in her own country after her marriage with an Indian. She tries hard to adjust herself with her Indian husband, his culture and his friends. To some extent, she succeeds in it but her own society is not ready to accept her as an Indian wife. She begins to feel alienated in her own society. Every moment she deliberately tries to avoid people talking about her life, her husband and India as well. She feels tortured about the loss of her own name and identity in her own society:

An anguish it seemed to her of loneliness and then it becomes absurd to call her by her own name-to call her by any name. She had become nameless, she had shed her ancestry and identity and she sat there staring, as though she watched them disappear (Bye-Bye Blackbird 3).

In the end, Sarah is given an unavoidable option by Adit to move back to India and being a woman how can she reject it. Despite being frustrated by their situations, most of the characters are trying to survive by making the ways of their own. 
In Custody marks a departure from Anita Desai's earlier novels where women sensibility is dealt with but this novel has a male protagonist who comes from a lower middle class family and who puts his step into a wider world in the hope of self fulfillment. Deven Sharma is a lecturer in Hindi in a college in Mirpore a small town near Delhi. A turning point comes in his life when his childhood friend Murad asks him to take an interview of the great poet Nur. He wants to publish this interview in his magazine. Deven agrees at once. He is aware of his personal incompetency of fulfilling his wife's dreams and desires. He lives with a sense of defeat and failure because he feels alone even with his wife:

He understood because like her, he had been defeated too; like her he was a victim. Although each understood the secret truth about the other, it did not bring about any closeness of spirit, any comradeship, because they also sensed that two victims, ought to avoid each other, not yoke together their joint disappointments (In Custody 40).

Finally, the proposal given by Murad makes him disappointed. Deven is entrapped gradually in Nur's world:

Deven's great rootless, restless, mobility, loneliness, and his paralyzing helplessness are objectified by the people with whom he comes in contact his wife, Sarla; Mr. Jain; and his two nephews; his colleague, Mr. Siddiqui; the head of the department, Mr. Trivedi, and the two wives of the poet (Inamdar 58).

Thus, Deven finds no sympathetic soul to console him instead he gets failure and frustration and his consciousness makes him realize, as R.K. Gupta points out that "reality is always depressing but the answer does not lie in escapist sense" (218). Now he realizes the ultimate truth of life:

He walked up the path. Soon the sun would be up and blazing. The day would begin, with calamities. They would flash out of the sky and cut him down like swords. He would run to meet them. He ran, stopping only to pull a branch of thorns from under him foot (In Custody 40).

Hence, the very struggle against failures shows him a spark of hope to survive in the battle of life.

'Accepting-not accepted' is the story of Hugo Baumgartner's life in Anita Desai's next novel Baumgartner's Bombay. It is ironical that he remains alone throughout his life not only in India but in his own country also. In India, he tries to maintain a distance with other Europeans because he did not like their "probing questions, their determination to discover his background, his circumstances, his past, and present and future, before they accepted him" (Baumgartner's Bombay 167). So he moves to Bombay. The behaviour of Chimanlal's sons and others at the time of cremation frustrates him deeply as it may be;

...all of whom shrank away from him, horrified by the presence of a foreigner, a 'firang' at such an intensely private rite. Hearing the babbling chant of the priests, seeking the confusion around the pyre, smelling the odours of burnt flesh and charred wood under the noontime sun, Baumgartner too wished he had not come, and shuffled away (Baumgartner's Bombay 214).

After living thirty years in Bombay, he fails to enter in its life and the city too remains absolutely unknown to him. This his life becomes the tale of betrayal given by his own country by separating him from his mother, by India where he is deceived, arrested, humiliated, being considered as a 'firangi' is killed at last by the boys 
without thinking the fact that he was the same person who saves his life by giving him shelter in his own house.

Lotte is another victim of the struggle for existence. She marries Kanti but she is rejected by his family. After Kanti's death, she is kicked out of the house given by Kanti. Although Lotte is alone yet she is able to survive. In fact, Baumgartour is also an isolated fellow but after understanding life deeply he has learnt to live in isolation. But the irony is that death does not spare him even in his isolation and of course, he becomes the most pitiable victim before and after his life.

To conclude, Anita Desai particularly deals with the institution of marriage in her novels where woman is the victim. She is caught in the trap of marriage and she finds only two ways. First, she denies such a miserable life and commits suicide and second, she lives but in alienation:

To revolt against injustice is human and if the victim is hypersensitive, the situation becomes sensitive enough. If the victim is sensitive young woman, her actions may ratter be intense-alternating between the two extremes of resignation and rebellion. In either case, the victims, as in Anita Desai's fiction, is driven into herself in order to realise one's own self. Anita Desai's female protagonists perceive the psychic truth which is distinctly different from the reality confront. They develop fears obsessions, neuroses, paranoia or schizophrenia and gradually withdraw from the society including their families and husbands. They develop in communication and tend to ponder over existential problems and end up in alienation (George 162).

Thus, alienated life becomes the fate $o$ f Anita Desai's women protagonists who are survivors. Here, living is not the matter but the matter is how long a person can survive alone.

\section{REFERENCES}

[1]. Desai, Anita. Bye-Bye Blackbird. Delhi: Orient Paperbacks, 1985.

---Baumgartner's Bombay. London: Heinemann, 1988.

---Cry, the Peacock. Delhi. Vision Books, 1983.

--- In Custody. USA: Penguin, 1984.

---Voices in the City. Delhi: Orient Paperbacks, 1988.

[2]. George, C.V. "Alienation of Women Characters in Anita Desai's Novels." The Novels of Anita Desai: A Critical Study. Ed. Manmohan K. Bhatnagar \& M. Rafeshwar. New Delhi: Atlantic, 2000.

[3]. Gupta, R.K. The Novels of Anita Desai: A Feministic Perspective. New Delhi: Atlantic, 2002.

[4]. Inamdar, F.A. "Fetters of Illusion. In Custody". Indian Women Novelists. Ed. R.K Dhawan. Vol. 4. New Delhi: Prestige, 1991.

[5]. Pandey, Prabhat Kumar. "The Lonely Voyage: Feminine Psyche in Cry, the Peacock." Indian Women Novelists. Ed. R.K. Dhawan. Vol. III. New Delhi: Prestige Books, 1991

[6]. Rao, A.V. Krishna. "Voices in the City: A Study". Perspectives on Anita Desai. Ed. Ramesh, K. Srivastava. Ghaziabad: Vimal, 1984. 
Cite this article as : Dr. Pinky, "Conflict between Individual and Society : A Brief Review of Victims and Survivors in Anita Desai's Fiction ", International Journal of Scientific Research in Science and Technology (IJSRST), Online ISSN : 2395-602X, Print ISSN : 2395-6011, Volume 6 Issue 2, pp. 738-743, March-April 2019. Available at doi : https://doi.org/10.32628/IJSRST1962148

Journal URL : http://ijsrst.com/IJSRST1962148 